\title{
Interference of aldicarb in infective forms of Meloidogyne incognita and its effects on reproduction in soybean
}

\author{
Esdras Henrique da Silva ${ }^{1}$, Vicente Paulo Campos ${ }^{2}$, Fernando da Silva Rocha ${ }^{3}$, Walmes \\ Marques Zeviani ${ }^{4}$, Willian César Terra ${ }^{2}$, Renê Luís de Oliveira Rigitano \\ ${ }^{1}$ Instituto Federal do Tocantins, Campus Colinas do Tocantins, Palmas, Tocantins, Brasil. E-mail: esdras.silva@ifto.edu.br \\ ${ }^{2}$ Universidade Federal de Lavras, Lavras, Minas Gerais, Brasil. E-mail: vpcampos@dfp.ufla.br, terranema@gmail.com, \\ rigitano@ufla.br \\ ${ }^{3}$ Universidade Federal de Minas Gerais, Campus Montes Claros, Montes Claros, Minas Gerais, Brasil. E-mail: \\ rochafsplant@yahoo.com.br \\ ${ }^{4}$ Universidade Federal do Paraná, Campus III, Curitiba, Paraná, Brasil. E-mail: walmes@ufpr.br \\ Received: 10/02/2020; Accepted: 28/03/2020.
}

\section{ABSTRACT}

The effect of aldicarb on mortality, motility, and reproduction of $M$. incognita in soybean was studied. The mortality of second-stage juveniles (J2) in aldicarb solution (5 and $\left.50 \mu \mathrm{g} \mathrm{mL}^{-1}\right)$ was only high at 20 days of exposure, being higher in the concentration of $50 \mu \mathrm{g} \mathrm{mL} \mathrm{L}^{-1}$ and lower in control (water). Motility was inversely proportional to the exposure time, and at 20 days of incubation, the number of $\mathrm{J} 2$ mobiles was statistically equal for both concentrations evaluated. There was a reduction inversely proportional to the number of galls and eggs per gram of root according to the $\mathrm{J} 2$ incubation time in water and aldicarb $(5,10$, and 20 days). $\mathrm{J} 2$, when incubated in $50 \mu \mathrm{g} \mathrm{mL}^{-1}$ aldicarb for 5 and 10 days, always provided the same values regarding the number of galls and eggs per gram of root. The incubation for 20 days resulted in the loss of $\mathrm{J} 2$ infectivity, both in water and in aldicarb (5 and $50 \mu \mathrm{g} \mathrm{mL}^{-1}$ ), with practically no galls and eggs. When the $\mathrm{J} 2$ were incubated in the soil with the application of aldicarb solution (5 and $50 \mu \mathrm{g} \mathrm{mL}^{-1}$ ) or water (control), followed by soybean planting, 5, 10 and 20 days after, the $\mathrm{J} 2$ infectivity was null in the treatments with aldicarb $(5$ and $50 \mu \mathrm{g} \mathrm{mL}-1)$. However, when the J2-infested soil was sprayed with pure water (control), gall formation and reproduction decreased with the $\mathrm{J} 2$ incubation period, with a drastic reduction from the 5th day. Therefore, exposure to aldicarb affects the life cycle of $M$. incognita in soybeans.

Keywords: root-knot nematodes, chemical control, carbamate.

\section{Interferência de aldicarbe em formas infectivas de Meloidogyne incognita e seus efeitos sobre a reprodução em soja}

\section{RESUMO}

Estudou-se o efeito de aldicarbe na mortalidade, motilidade e reprodução de $M$. incognita em soja. A mortalidade de juvenis de segundo estádio (J2) em solução de aldicarbe $\left(5\right.$ e $\left.50 \mu \mathrm{g} \mathrm{mL}^{-1}\right)$ só foi elevada aos 20 dias de exposição, sendo maior na concentração de $50 \mu \mathrm{g} \mathrm{mL}^{-1}$ e menor no controle (água). A motilidade foi inversamente proporcional ao tempo de exposição, sendo que, aos 20 dias de incubação o número de $\mathrm{J} 2$ móveis foi estatisticamente igual para ambas as concentrações utilizadas no trabalho. O número de galhas e de ovos/g de raiz foi reduzido inversamente proporcional ao tempo de incubação do $\mathrm{J} 2 \mathrm{em}$ água e em aldicarbe (5, 10 e 20 dias). Os $\mathrm{J} 2$, quando incubados em aldicarbe $50 \mu \mathrm{g} \mathrm{mL}^{-1}$ por $5 \mathrm{e} 10$ dias, proporcionaram sempre os mesmos valores relativos a número de galhas e ovos/g de raiz. A incubação por 20 dias resultou em perda da infectividade do J2, tanto em água quanto em aldicarbe (5 e $50 \mu \mathrm{g} \mathrm{mL}^{-1}$ ), não ocorrendo praticamente galhas e ovos. Quando os J2 foram incubados no solo com aplicação de solução de aldicarbe $\left(5\right.$ e $\left.50 \mu \mathrm{g} \mathrm{mL}^{-1}\right)$ ou água (controle), seguido do plantio de soja, 5,10 e 20 dias após, a infectividade dos J2 foi nula nos tratamentos com aldicarbe ( 5 e $\left.50 \mu \mathrm{g} \mathrm{mL}^{-1}\right)$. Entretanto, quando o solo infestado com J2 foi irrigado com água pura (controle), a formação de galhas e a reprodução decresceram no período de incubação do $\mathrm{J} 2$, com redução drástica a partir do $5^{\circ}$ dia. Portanto, a exposição ao aldicarbe afeta o ciclo de vida de M. incognita em soja.

Palavras-chave: nematoides de galhas, controle químico, carbamato. 


\section{Introduction}

The second-stage juveniles (J2) of Meloidogyne incognita has limited energy reserve to reach the feeding site (Rocha et al., 2016), besides to be influenced by chemical molecules produced by plants that are present in the soil solution such as phenolic compounds, terpenoids, alkaloids, fatty acids, isothiocyanates, cyanogenic glycosides (Jardim et al., 2018; Campos et al., 2016).

The nematicides of the carbamate and organophosphate groups are synthetic organic substances widely used in agriculture that have acetylcholinesterase (AChE) inhibitory activity. AChE is the enzyme responsible for hydrolyzing the neurotransmitter acetylcholine (ACh) in cholinergic synapses. In these synapses, ACh acts by transmitting the message between neurons. Cholinergic synapses are widely distributed in the central and peripheral nervous system, is important for the maintenance of numerous physiological functions (Duerr et al., 2008).

Aldicarb, 2-Methyl-2-(methylthio)propionaldehyde O-(Methylcarbamoyl)oxime, is an example of a successful nematicide belonging to the carbamate group that has AChE inhibitory activity. This nematicide has been used for many years, providing a reduction in the population of Meloidogyne spp. in the soil and reducing damage to plants up to 40 days after application (Hough et al., 1975). The action mechanism of aldicarb is similar to several organic chemical molecules that may in the future be used as nematicides, such as, for example, the alkaloids eserine, sanguinarine, dehydroevodiamine, turbinatine and hamaine (Wang et al., 2012; Houghton et al., 2006). Thus, the study of the response of nematodes that were exposed to molecules with AChE inhibitory properties is significantly relevant.

AChE inhibition affects second-stage juveniles (J2) of Meloidogyne spp. inside the host, as well as outside it, in the soil solution (Sikora and Hartwig, 1991). Aldicarb acts directly on the root-knot nematode Heterodera rostochiensis and not indirectly by acting on the plant (Hague and Pain, 1973; Miller, 1970). It also prevents the penetration of the potato roots, resulting in the accumulation of $\mathbf{J} 2$ of $H$. rostochiensis in the soil (Steele and Rodges, 1975) and affects the migration of $\mathrm{J} 2$ in the soil and motility in solutions (Huang et al., 1983; Sikora and Hartwig, 1991). The evolution of knowledge from these studies leads to the conceptualization of aldicarb as a molecule that interferes in the cycle of root-knot nematodes, acting in the temporary and reversible immobilization of $\mathrm{J} 2$ in the soil, being, then, a molecule with nematostatic effect. (Nelmes, 1970; Rocha and Campos, 2003).

Research on incubation of $\mathrm{J} 2$ of Meloidogyne spp. in the water at $28^{\circ} \mathrm{C}$, demonstrated that the infectivity of these $\mathbf{J} 2$ decreases with the incubation time (Rocha et al., 2015; Freire et al., 2007). Rocha et al. (2015) found that the decrease in the lipid content of $\mathrm{J} 2$ of $M$. incognita affects its infectivity and reproduction differently with incubation. After six days of storage of the $\mathrm{J} 2$ of $M$. incognita, there were losses more than $50 \%$ of the neutral lipid content concerning the initial level; and the decrease in lipid content with the incubation period was correlated with the reduction in the number of galls and eggs of $M$. incognita in tomato plants. Also, a study by Andaló et al. (2009), show that J1 of Heterorhabditis amazonensis, incubated in herbicide solution, had accelerated loss of body energy without the occurrence of mortality.

Given the importance of AChE as a target for bioactive molecules, the evaluation of the potential that compounds have in inhibiting AChE has high relevance for the development of new nematicides (Kang et al., 2013). Comprehensive studies with a single species of nematode and host will lead to a better understanding of the additive effects of $\mathrm{AChE}$ inhibition, in the various phases of the life cycle of Meloidogyne spp. For this, in this work, $M$. incognita and soybean as hosts were used.

Efficacy of aldicarb in control of phytonematodes appears to be correlated with the food shortage time of $\mathrm{J} 2$ and the exposure to the nematicide in both soil and solution (Nelmes, 1970; Steele and Rodges, 1975). Thus, it was decided to deepen studies on aldicarb effect on $\mathrm{J} 2$ of $M$. incognita in soybean, involving the evaluation of mortality and reproduction of nematode after incubation of $\mathrm{J} 2$ for different times and aldicarb concentrations, both in solution and soil sprayed with the nematicide.

\section{Material and Methods}

\section{1) Preparation of the aldicarb stock solution}

The aqueous stock solution of aldicarb, at the expected concentration of $500 \mu \mathrm{g} \mathrm{mL}^{-1}$, was prepared by adding $6.66 \mathrm{~g}$ of the commercial formulation Temik ${ }^{\circledR}$ $150 \mathrm{G}$ in $1,000 \mathrm{~mL}$ of water contained in an Erlenmeyer flask, which was placed on a shaker table for 30 minutes. Then, the aqueous phase was filtered through cotton placed at the bottom of a funnel and kept in a refrigerator at $8^{\circ} \mathrm{C}$.

Aliquots were obtained to evaluate the aldicarb content in solution, using high-performance liquid chromatography at the Laboratório de Toxicologia de Inseticidas (Insecticide Toxicology Laboratory) at the Universidade Federal de Lavras (Federal University of Lavras). Dilutions of the stock solution (authors' methodology) were made to obtain the concentrations used in the tests. The tests were carried out before the registration of the commercial product used in this study was canceled. 
In previous studies (unpublished data), it was observed that the concentrations of aldicarb 5 and $50 \mu \mathrm{g}$ $\mathrm{mL}^{-1}$, which can be found more frequently in agricultural soil, cause moderate and high toxic effects in $\mathrm{J} 2$, respectively, and that is why they were used in all tests.

\section{2) Obtaining J2 from Meloidogyne incognita}

Roots of tomato plants (Solanum lycopersicum Mill.) cv. Kada has grown in a greenhouse and infested with $M$. incognita from a pure population identified by electrophoresis (Carneiro and Almeida, 2001) were washed carefully and cut into $1 \mathrm{~cm}$ pieces. Then, they were crushed in a blender for 20 seconds, in a $0.5 \%$ sodium hypochlorite solution, following the technique of Hussey and Barker (1973), modified by Bonetti and Ferraz (1981). The eggs retained in the $0.025 \mathrm{~mm}$ sieve were collected in a $200 \mathrm{~mL}$ beaker using a wash bottle. The egg suspension was placed in a hatching chamber and maintained at a temperature of $25^{\circ} \mathrm{C}$. Only the $\mathrm{J} 2$ hatched on the third day was used in the tests.

\section{3) Obtaining soybean seedlings}

Soybean seeds (Glycine max L.) cv. Doko were distributed in plastic trays previously disinfected with 95\% alcohol, which contained sand moistened with water. Then, they were placed in an air-conditioned chamber, with 14 hours of light and 10 hours of no light, at a temperature of $27 \pm 2{ }^{\circ} \mathrm{C}$, to allow germination. After 72 hours, seeds germinated with a radicle of $2 \mathrm{~cm}$ in length were selected for use in the tests.

\section{4) Effect of exposure time and aldicarb concentrations on $\mathbf{J} 2$ mortality and motility}

$\mathrm{J} 2$ of $M$. incognita were incubated at $25^{\circ} \mathrm{C}$, for 5,10 , and 20 days, in aldicarb solutions, in concentrations of 0 , 5 , and $50 \mu \mathrm{g} \mathrm{mL}^{-1} .5 \mathrm{~mL}$ of the solutions were placed in glass flasks with a capacity of $15 \mathrm{~mL}$ and pipetted $100 \mu \mathrm{L}$ of a suspension in which there were $100 \mathrm{~J} 2$ recently hatched and $100 \%$ mobile. After the incubation times, the $\mathrm{J} 2$ suspension was poured through an $11 \mu \mathrm{m}$ sieve to remove all aldicarb solution. The $\mathrm{J} 2$ retained in the sieve were washed twice in tap water and removed, with jets of water from a wash bottle, into the same glass flasks used in the incubation. After removing aldicarb, the J2 was kept in $5 \mathrm{~mL}$ of water and incubated at $25^{\circ} \mathrm{C}$ for 24 hours. After, $\mathrm{J} 2$ of each flask was transferred to Elisa plates, in which the number of mobile, immobile, and dead J2 were evaluated. Mortality evaluation was performed according to the methodology described by Chen and Dickson (2000). A completely randomized design with four replications was used, in a 3 x 3 factorial scheme, three concentrations (zero concentration was used as a control) and three incubation times.
5) Reproduction of Meloidogyne incognita from J2 incubated in solution or soil moistened with aldicarb

$\mathbf{J} 2$ incubated in solution: the $\mathbf{J} 2$ were incubated for 5 , 10 , and 20 days in aldicarb solutions at 5 or $50 \mu \mathrm{g} \mathrm{mL}^{-1}$ at $25^{\circ} \mathrm{C}$. The $\mathrm{J} 2$ incubated in distilled water was used as control. After this period, the $\mathrm{J} 2$ was separated from the aldicarb solution, washed twice in water, and packed in a flask to carry out the inoculation. For inoculation, soybean seedlings were transplanted in $250 \mathrm{~g}$ of a substrate composed of soil and sand substrate $(2: 1)$, autoclaved for 2 hours at $120{ }^{\circ} \mathrm{C}$, in $300 \mathrm{~mL}$ plastic cups and kept in an air-conditioned chamber with 14 hours of light and 10 hours of no light, at a temperature of $27 \pm 2$ ${ }^{\circ} \mathrm{C}$. After four days of transplanting, the $\mathrm{J} 2$ dispersed in $4 \mathrm{~mL}$ of water and distributed in four holes $3 \mathrm{~cm}$ deep, made around the seedlings, was inoculated.

$\mathbf{J} 2$ incubated in soil: in this trial, the $\mathbf{J} 2$ were incubated in the soil, treated with aldicarb, for $0,5,10$, and 20 days before seedling transplanting. In plastic cups with $250 \mathrm{~g}$ of a substrate composed of soil and sand substrate (2:1), aldicarb solutions at 5 or $50 \mu \mathrm{g} \mathrm{mL}^{-1}$ per cup were added until reaching $60 \%$ of the field capacity. In control, distilled water was added. In the center of the substrate, of each cup, a plaster mold coated with paraffin was placed in the same shape, size, and volume of the cells of the Styrofoam tray (144 cells) where the soy seedlings were produced. Seven hundred J2 were dispersed in $2 \mathrm{~mL}$ of water and placed in 4 holes made with the aid of a glass stick, at a depth of $3 \mathrm{~cm}$ around the plaster mold, of each cup. The holes were covered with the same substrate. Then, the plastic cups were placed in BOD incubators at $25{ }^{\circ} \mathrm{C}$, and the soil moisture was maintained at $60 \%$ of the field capacity, with daily irrigation with water. At $0,5,10$, and 20 days, the plaster molds were replaced by soybean seedlings. Soybean was sown in trays of 144 cells containing the same shape as the plaster mold and substrate used in the cups, which were kept in an airconditioned room under the conditions already mentioned above. After ten days, the plants were transplanted into the cups.

In the experiment in which $\mathrm{J} 2$ were incubated in solution, the completely randomized design was used with four replications, in a $3 \times 3$ factorial scheme, three concentrations (zero concentration was used as a control) and three incubation times. In the experiment in which $\mathrm{J} 2$ was incubated in the soil, the same design with five replications was used in a $3 \times 4$ factorial scheme, three concentrations, and four incubation times $(0,5,10$, and 20 days). At the zero-time, soybean seedlings were transplanted immediately after the inoculation of $\mathrm{J} 2$ in the soil. 
In both trials, reproduction was evaluated at 35 days after soybean transplantation. The shoot was cut, and the root system, together with the soil, was placed in the water contained in a 10-liter bucket and carefully separated from the soil. The roots were left on paper towels for 10 minutes to remove excess water and weighed. Then, the number of galls in the root system was counted. The roots were processed to quantify the number of eggs per root system using the technique described by Hussey and Barker (1973), modified by Bonetti and Ferraz (1981). In an inverted microscope, the number of $M$. incognita eggs per root system was quantified. Then, the number of galls per root system, and eggs per gram of root was estimated.

Statistical analysis: the data obtained in all tests were submitted to joint analysis of variance (mean values of repeated tests) and to the Tukey test, at $5 \%$ probability, to compare the means. The significant variables by the $\mathrm{F}$ test were subjected to regression analysis to adjust the best model capable of describing the biological phenomenon in question. The analyses were performed using the software R (R Development Core Team, 2009). All tests performed in this study were repeated twice in space and time, proving the results. The data presented are the average of the two repetitions.

\section{Results and Discussion}

The $\mathrm{J} 2 \mathrm{~s}$ exposed to aldicarb suffered changes in motility and mortality. Mortality of $\mathrm{J} 2$ at 20 days of incubation in water or aldicarb increased significantly compared to other periods. Compared to the control $(\mathrm{P} \leq 0.05)$, the highest mortality $(84 \%)$ occurred during incubation in aldicarb, at a concentration of $50 \mu \mathrm{g} \mathrm{mL}^{-1}$. The mortality of $\mathrm{J} 2$ in the concentrations ( 5 and $50 \mu \mathrm{g}$ $\mathrm{mL}^{-1}$ ) of aldicarb at 5 and 10 days of incubation ranged between 9.75 and $13 \%$ (Figure 1). Natural mortality, which occurred at 20 days of incubation in water, was

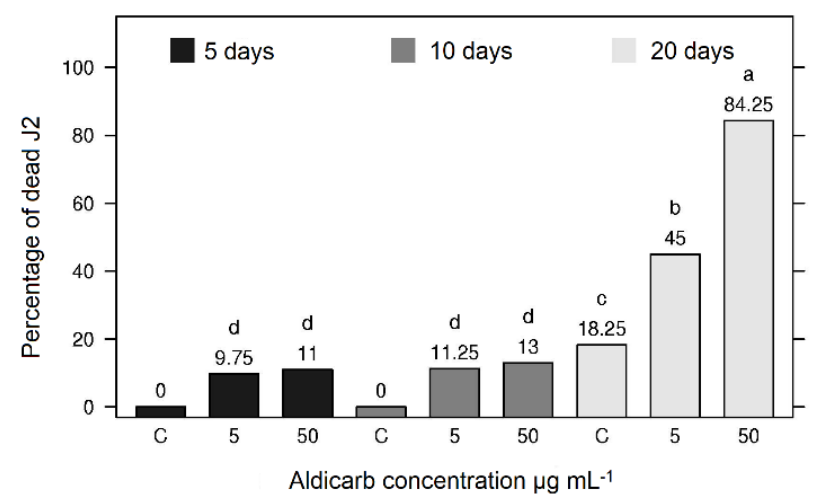

Figure 1: Percentage of second-stage juveniles (J2) of Meloidogyne incognita dead after incubation in aldicarb solutions for several periods. $\mathrm{C}=$ control, $\mathrm{J} 2$ incubated in pure water. Bars followed by the same letter do not differ, according to the Tukey test, at 5\% probability. statistically higher than that observed with incubation for 5 or 10 days in both concentrations of aldicarb (5 and $50 \mu \mathrm{g} \mathrm{mL}^{-1}$ ).

$\mathrm{J} 2$ immobility was inversely proportional to $\mathrm{J} 2$ incubation time. The decrease in motility ranged with the incubation time, and the number of immobile $\mathrm{J} 2$ at the concentration of $50 \mu \mathrm{g} \mathrm{mL}-1$ was the highest. However, after 20 days of incubation, the number of immobile J2 was statistically equal in both concentrations (Figure 2).

The aldicarb concentration and exposure time of $\mathrm{J} 2$ to the nematicide define the levels of immobility, mortality, and return to motility once the exposure to the nematicide has ceased. The effect of aldicarb on motility starts at low concentrations, whereas mortality occurs at high concentrations and over longer periods of exposure to the nematicide.

Reversible motility can characterize the nematostatic effect. Silva et al. (2019) observed the occurrence of $90 \%$ immobilization of $\mathrm{J} 2$ in aldicarb after 24 hours of incubation; and that after removing the solution, the incubating of $\mathrm{J} 2$ in water causes increase in the mobility with the incubation time; and $\mathrm{J} 2$ incubated in lower concentrations $\left(1,5\right.$ and $\left.10 \mu \mathrm{g} \mathrm{mL}^{-1}\right)$ reached more than $90 \%$ motility in $24 \mathrm{~h}$ incubation at $25^{\circ} \mathrm{C}$.

This differential effect between the periods of 20 days and the others (5 and 10 days) is defined as two physiological conditions distinct of $\mathrm{J} 2$ and with different sensitivities to the nematicide, occurring, then, synergistic interaction between the aldicarb and the period of 20 days with food shortages. As the incubation temperature was $25^{\circ} \mathrm{C}$, the $\mathrm{J} 2$ incubated in the solutions indicated they spent the reserve energy that came from the embryonic development. Possibly, when this energy level is still high (at ten days), the lethal effect of aldicarb is very low. On the other hand, when this energy declines appreciably (20 days), the lethal effect of the nematicide is drastic and with a differential response between concentrations.

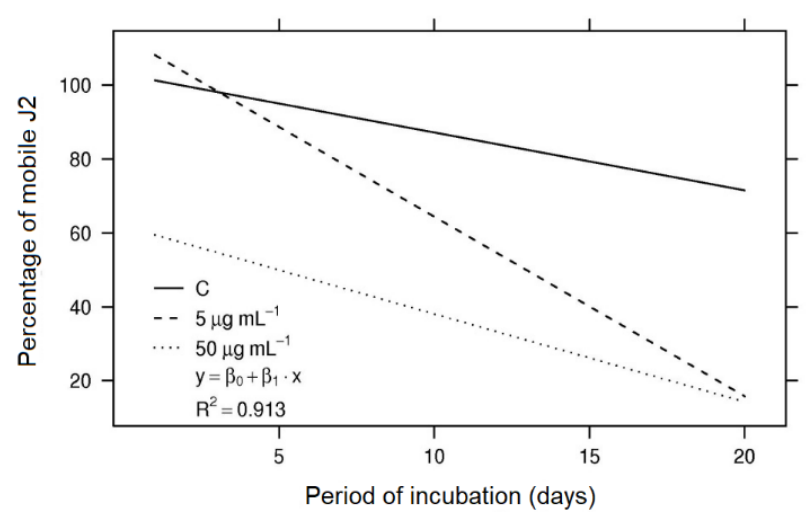

Figure 2: Percentage of mobile second-stage juveniles (J2) of Meloidogyne incognita, after incubation in aldicarb solution (5 or $50 \mu \mathrm{g} \mathrm{mL}^{-1}$ ) for several periods and return to pure water for 24 hours. $0=$ control, the $\mathrm{J} 2$ was incubated in pure water. 
Silva et al. (2019) observed that the neutral lipids body content of $\mathrm{J} 2$ incubated in aldicarb at 5 and $50 \mu \mathrm{g}$ $\mathrm{mL}^{-1}$ was similar to that incubated in water until the 8th day, despite high immobility. However, on the 12th day, the $\mathrm{J} 2$ incubated in water showed higher decreases in body lipid content than the $\mathrm{J} 2$ incubated in aldicarb. Although the $\mathrm{J} 2$ are immobile when incubated in aldicarb, energy expenditure has occurred, perhaps due to the transmission of stimuli by neurons occurring in an uncontrolled manner, since the process regulating enzyme (AChE) is inactivated by the aldicarb (Opperman and Chang, 1991). Higher energy expenditure occurs in $\mathrm{J} 1$ of $H$. amazonensis incubated for five days in herbicides than $\mathrm{J} 1$ incubated in pure water (Andaló et al., 2009). Van Gundy et al. (1967) found that storage in the pure water of M. javanica J2, at $25{ }^{\circ} \mathrm{C}$, for four days, caused a lipid loss of $41.33 \%$; however, it did not affect the motility of $\mathrm{J} 2$.

Several neurotransmitters have been found in nematodes, such as acetylcholine, gamma-aminobutyric acid (GABA), dopamine, and several neuropeptides (Stewart et al., 2001; Stewart et al., 1994; Schuske et al., 2004; Wright and Perry, 2006). However, it is only known that aldicarb inhibits the acetylcholinesterase enzyme that controls the neurotransmitter acetylcholine (Opperman and Chang, 1991). In a sand column under continuous exposure to aldicarb ( 1 and $5 \mu \mathrm{g} \mathrm{mL}^{-1}$ ), the migration of $\mathrm{J} 2$ of $M$. javanica and $H$. schachtii is inhibited (Hough and Thomason, 1975). J2 of Globodera rostochiensis has the motility reduced within 24 hours of exposure to aldicarb at $10 \mu \mathrm{g} \mathrm{mL}^{-1}$, and only $67 \%$ of them return to mobility in water (Nelmes, 1970). Although live nematodes are selective as to the

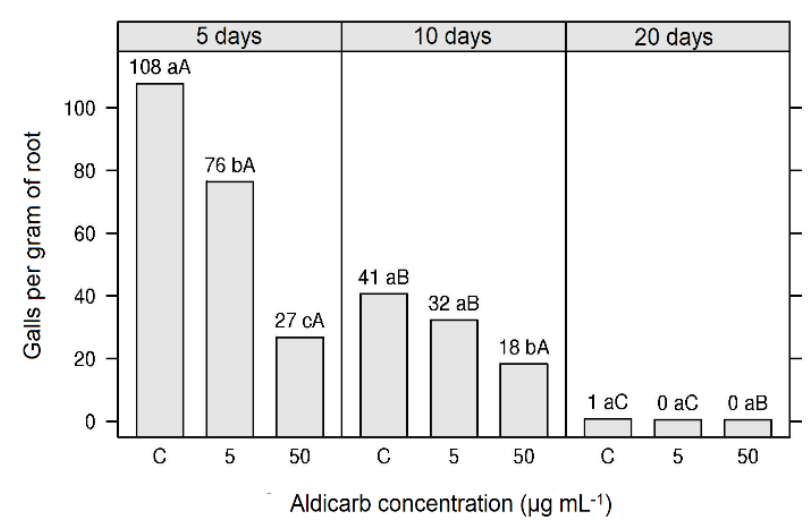

Figure 3: Average number of galls per gram of soybean root resulting from inoculation of second-stage juveniles (J2) of Meloidogyne incognita incubated in aldicarb solution for several periods in vitro. $\mathrm{C}=$ control, $\mathrm{J} 2$ incubated in pure water in vitro. Lowercase letters compare the concentrations within each incubation period (days), and uppercase letters compare each concentration in the different incubation periods (days). Bars followed by the same letter do not differ, according to the Tukey test, at 5\% probability. permeation of some substances in their tissues, the cuticle is not a barrier to halogenated hydrocarbons. Nelmes (1971) demonstrated that aldicarb is rapidly absorbed by Panagrellus redivivus and reaches equilibrium with the external solution in 30 minutes. However, within the nematode, the substance can be stored in tissue with no vital function for the organism. The nematode can detoxify, excrete the toxic substance, or avoid toxicity (Van Gundy and Mckerry, 1977). In $P$. redivivus, aldicarb is quickly transformed into less toxic aldicarb-sulfoxide (Nelmes, 1971).

The number of galls and eggs of $M$. incognita in soybeans from inoculation of $\mathbf{J} 2$ incubated in both pure water and aldicarb for 20 days were very low and statistically equal (Figures 3 and 4). Therefore, the effects resulting from the factors of incubation time and aldicarb concentration were only manifested during the first ten days of incubation.

The $\mathrm{J} 2$ incubation for 10 days resulted in a reduction in the number of galls (50\%) and eggs (20 to 50\%) of $M$. incognita both by $\mathrm{J} 2$ incubated in pure water (control) and concentration of $5 \mu \mathrm{g} \mathrm{mL}^{-1}$ of aldicarb, compared to the 5day incubation period (Figures 3 and 4). At 5 days of J2 incubation, aldicarb (5 and $\left.50 \mu \mathrm{g} \mathrm{mL}^{-1}\right)$ reduced $(\mathrm{P} \leq 0.05)$ the number of galls compared to the control (water incubation), with a higher reduction for $\mathrm{J} 2$ incubated in the concentration $50 \mu \mathrm{g} \mathrm{mL}^{-1}$ (Figure 3). At 10 days, only the concentration of $50 \mu \mathrm{g} \mathrm{mL}^{-1}$ reduced the number of galls concerning the other treatments (Figure 3). The number of eggs at both 5 and 10 days of $\mathrm{J} 2$ incubation was reduced by aldicarb ( 5 and $50 \mu \mathrm{g} \mathrm{mL}^{-1}$ ) compared to the control, with a higher reduction when $\mathrm{J} 2$ was incubated at aldicarb concentration of $50 \mu \mathrm{g} \mathrm{mL} \mathrm{m}^{-1}$ (Figure 4).

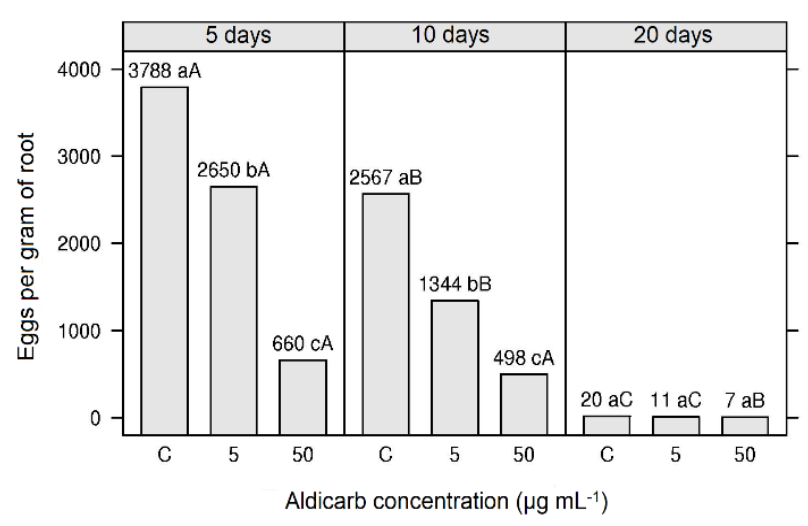

Figure 4: Average number of eggs per gram of soybean root resulting from inoculation of second-stage juveniles (J2) of Meloidogyne incognita incubated in aldicarb solution for several periods "in vitro". $\mathrm{C}=$ control, $\mathrm{J} 2$ incubated in pure water in vitro. Lowercase letters compare the concentrations within each incubation period (days), and uppercase letters compare each concentration in the different incubation periods (days). Bars followed by the same letter do not differ, according to the Tukey test, at 5\% probability. 
The synergistic effect of aldicarb $\left(5\right.$ and $\left.50 \mu \mathrm{g} \mathrm{mL}^{-1}\right)$ with the time (20 days) of incubation (Figure 1) does not offer benefits in the control of $M$. incognita, because in this period (20 days) the $\mathrm{J} 2$ does not have an infectious capacity (Figures 3 and 4). In this way, the $\mathrm{J} 2$ lose their infectious capacity before the loss of motility. This $\mathrm{J} 2$ population in the field, verified by soil extraction, had not expressed the risk of damage to the crop and should not receive a recommendation for control.

During 10 days of food shortage, the aldicarb effects are possibly linked to the reduction of the attraction of $\mathrm{J} 2$ by the roots, in addition to other physiological damages, such as less use of nutrients in giant cells. While the reproduction of $M$. incognita resulting from $\mathrm{J} 2$ incubated for 10 days in aldicarb at $5 \mu \mathrm{g} \mathrm{mL}-1$ was different $(\mathrm{P} \leq 0.05)$ from that of the control, the gall formation was similar $(\mathrm{P} \leq 0.05)$. This result indicates, although the penetration and success in the formation of giant cell occurred, the capacity of the giant cell may have been deficient or the physiology of the J2 incubated in the aldicarb at $5 \mu \mathrm{g} \mathrm{mL}^{-1}$ may have been affected deleteriously by the nematicide in which refers to the use of nutrients available in giant cells.

The solution of $50 \mu \mathrm{g} \mathrm{mL}^{-1}$ of aldicarb provided an effect on $\mathrm{J} 2$ during the incubation more pronounced in events already mentioned, or in other aspects of the direction of nematode and its physiology, as it has always significantly reduced the number of galls and eggs of M. incognita. Steele and Hodges (1975) found that $\mathrm{J} 2$ of $H$. schchtii stored for 4,8 and 14 days in aldicarb solutions $\left(0.1 ; 2\right.$ and $\left.5 \mu \mathrm{g} \mathrm{mL}^{-1}\right)$ had lower values of infectivity and reproduction when compared to J2 incubated in water, and this reduction was inversely proportional to the incubation time (days) and concentrations.

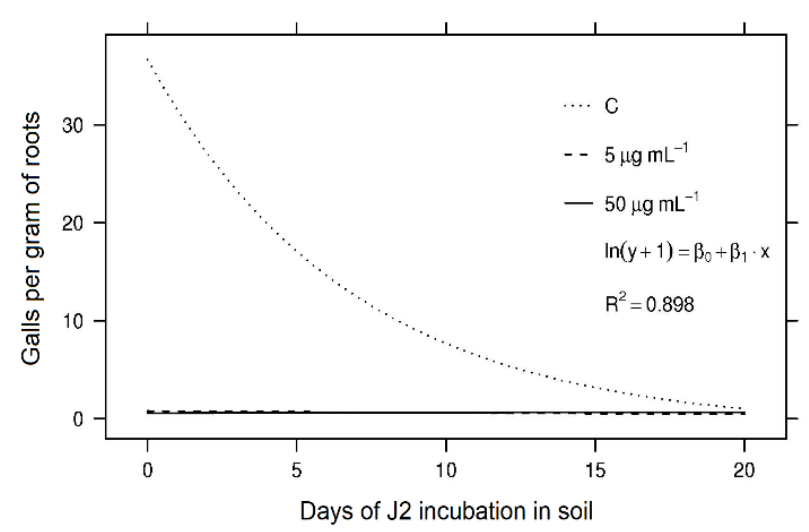

Figure 5: Average number of galls per gram of soybean root, resulting from the incubation of second-stage juveniles (J2) of Meloidogyne incognita in the substrate with aldicarb for several periods. $\mathrm{C}=$ control, $\mathrm{J} 2$ incubated in pure water on the substrate.
The exposure of $\mathbf{J} 2$ to aldicarb affected penetration in soybean, reducing it to a concentration of $150 \mu \mathrm{g} \mathrm{mL}^{-1}$. However, when aldicarb was irrigated in the soil before inoculation, no $\mathrm{J} 2$ was observed in the roots, indicating that the product affected the orientation of $\mathrm{J} 2$ towards the root tip or temporarily immobilized it (Silva et al., 2019).

Incubation of $\mathbf{J} 2$ in the substrate with application of aldicarb for 5, 10 and 20 days before planting soybeans did not provide the formation of galls or eggs in the roots, in any period. However, in incubation in soil irrigated with pure water, gall formation and the reproduction of $M$. incognita decreased with the incubation period of $\mathrm{J} 2$, with a drastic reduction from the 5 th day. The reduction in the number of eggs with $\mathrm{J} 2$ incubation time was faster than the reduction of galls per gram of soybean root (Figures 5 and 6).

Aldicarb in the soil solution (Figures 5 and 6) caused more drastic effects in $\mathrm{J} 2$ than in vitro solution (Figures 3 and 4) before inoculation, interrupting the life cycle of $M$. incognita. Considering that after the $\mathrm{J} 2$ incubation times for 5 and 10 days in vitro and subsequent washing and incubation in water, it provided a return of motility in more than $40 \%$ of the $\mathrm{J} 2$ (Silva et al. 2019). It is known that immobilization during the period of exposure to aldicarb is total, while incubation in aldicarb in vitro and subsequent washing of the nematodes in water before inoculation, perhaps, allows the detoxification and reversibility of immobilization, causing the $\mathrm{J} 2$ to become infectious, but with lesser effects on gall formation and the reproduction (Figures 3 and 4). The effect of aldicarb during the incubation of $\mathrm{J} 2$ in the soil (Figures 5 and 6) probably occurred due to the immobilization of $\mathrm{J} 2$ in the soil. Immobilization of $\mathrm{J} 2$ and simultaneous loss of body energy may also have occurred, as occurs with $\mathrm{J} 1$ of $H$. amazonensis incubated in herbicide solution (Andaló et al., 2009).

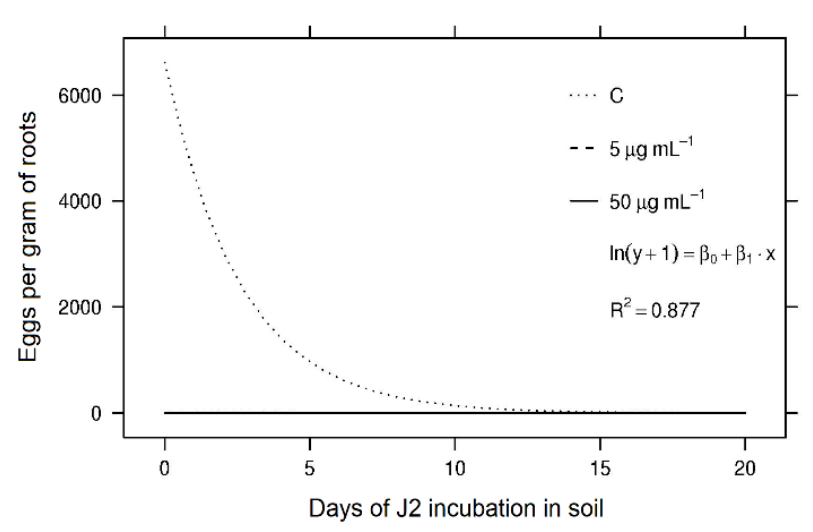

Figure 6: Average number of eggs per gram of soybean root, resulting from the incubation of second-stage juveniles (J2) of Meloidogyne incognita in the substrate with aldicarb for several periods. $\mathrm{C}=$ control, $\mathrm{J} 2$ incubated in pure water on the substrate. 
Silva et al. (2019) observed that when the aldicarb solution in concentrations of 5 and $50 \mu \mathrm{g} \mathrm{mL}-1$ were poured into the soil at 5,10 or 15 days after the inoculation of healthy $\mathrm{J} 2$ in soybeans, the reproduction of $M$. incognita (eggs/g root), was significantly reduced, with a higher reduction in the concentration of $50 \mu \mathrm{g}$ $\mathrm{mL}^{-1}$ than the control. Aldicarb at a concentration of $11.5 \mu \mathrm{g} \mathrm{mL}^{-1}$ in the soil solution can suppress the penetration and development of $H$. schachtii (Steele and Hodges, 1975). The concentration of $10.6 \mu \mathrm{g} \mathrm{mL}-1$ applied to the soil inhibited the reproduction and development of Tylenchulus semipenetrans females for 50 days (Huang and Van Gundy, 1976). Aldicarb affects the migration of $\mathrm{J} 2$ in the soil and its motility in solutions (Huang et al., 1983; Sikora and Hartwig, 1991). Hafez and Sudararaj (2000) observed $100 \%$ control when $\mathrm{J} 2$ of $M$. incognita were incubated for 14 , 21,28 , and 35 days in soils treated with $4.5 \mathrm{~kg}$ of aldicarb per hectare. However, after 20 days of the application of aldicarb in the soil, the effects on $\mathrm{J} 2$, and the Meloidogyne spp. cycle diminishes due to its degradation in the soil, becoming molecules less toxic to phytonematodes, aldicarb-sulfone, and aldicarbsulfoxide, or due to their leaching (Steele and Hodges, 1975; Piffer and Rigitano, 1991).

The drastic reduction in the number of galls and eggs resulting from the incubation of $\mathrm{J} 2$ in the soil to which no aldicarb solutions were added (Figures 5 and 6 ), from the 5th day onwards, it seems, resulted in falls in infectivity and body energy during the food shortage period. Freire et al. (2007) found that reproduction and infectivity of $\mathrm{J} 2$ of $M$. incognita stored at $28{ }^{\circ} \mathrm{C}$ decreased, over six days of storage, in soil (Neossolo Quartzarênico) with a sandy texture.

The decrease in the lipid content in $\mathrm{J} 2$ of $M$. incognita affects its infectivity and reproduction differently, with the storage time. At six days of storage of the $\mathrm{J} 2$ of $M$. incognita, there were losses of more than $50 \%$ of the neutral lipid content concerning the initial level, and there is a decrease in the lipid content with storage, correlating with the reduction in the number of galls and eggs of $M$. incognita (Rocha et al., 2015; Silva et al., 2019). Campos et al. (2006) verified losses of $38.82 \%$ and $56.12 \%$ in body lipid of $\mathrm{J} 2$ of $M$. javanica after the second and fourth day of storage in still water at $28^{\circ} \mathrm{C}$, which reflected a reduction of $44,64 \%$ in egg production and $73.68 \%$ in the number of females, respectively.

Aldicarb, an AChE inhibitor, acts with nematostatic and nematicidal effects in a deleterious way on the nematode's life cycle, interferes in $\mathrm{J} 2$ infectivity, in plant-nematode relationships and the reproduction of $M$. incognita in soybeans and interact, synergistically, at 20 days of exposure to the nematicide.

\section{Conclusions}

Aldicarb affected synergistically with the time of exposure to the motility and reproduction of $M$. incognita, with a higher effect on reproduction from the tenth day on which the nematode was in contact with the molecule. Thus, molecules that have effects analogous to aldicarb are nematostatic; however, with the increase in the period of exposure of the molecule, the nematode becomes incapable of causing damage to the plant.

\section{Bibliographic References}

Andaló, V., Moreira, G.F., Maximiniano, C., Moino Junior, A., Campos, V.P., 2009. Influence of herbicides on lipid reserves, mortality and infectivity of Heterorhabditis amazonensis (Rhabditida: Heterorhabditidae). Nematologia Mediterranea, Bari, 37(1), 11-15

Bonetti, J.I.S., Ferraz, S., 1981. Modificações do método de Hussey \& Barker para extração de ovos de Meloidogyne exigua em raízes de cafeeiro. Fitopatologia Brasileira, 6(1), 553.

Campos, H.D., Campos, V.P., Pozza, E.A., 2006. Efeito do tempo e da temperatura de incubação de juvenis do segundo estádio (J2) no teor de lipídio corporal e no parasitismo de Meloidogyne javanica em soja. Fitopatologia Brasileira, 31(4), 387-393.

Campos, V.A.C., Machado, A.R.T., Silva, W.J.R., Lopes, K.C., Terra, W.C., Campos, V.P., Oliveira, D.F., 2016. Estirillactonas de Cryptocarya aschersoniana Mez. (Lauraceae Juss.) com atividade contra Meloidogyne spp. e interação in silico com provável fumarase de Meloidogyne hapla. Química Nova, 39(2), 130-136.

Carneiro, R.M.D., Almeida, M.R.A., 2001. Técnica de eletroforese usada no estudo de enzimas dos nematoides de galhas para identificação de espécie. Nematologia Brasileira, 25(1), 35-44.

Chen, S.Y., Dickson, D.W., 2000. A technique for determining live second-stage juveniles of Heterodera glycines. Journal of Nematology, 32(1), 117-121.

Duerr, J.S., Han, H.P., Fields, S.D., Rand, J.B., 2008. Identification of Major Classes of Cholinergic Neurons in the Nematode Caenorhabditis elegans. The Journal of Comparative Neurology, 506(3), 398-408.

Freire, E.S., Campos, V.P., Dutra, M.R., Rocha, F.S., Silva, J.R.C., Pozza, E.A., 2007. Infectividade de juvenis do segundo estádio de Meloidogyne incognita em tomateiro após privação alimentar em solo e água em diferentes condições. Summa Phytopathologica, 33(3), 270-274.

Hafez, S.L., Sundararaj, P., 2000. Efficacy and persistence of nematicides against root-knot nematode, Meloidogyne incognita on tomato. Indian Journal of Nematology, 10(1), 37-40.

Hague, N.G.M., Pain, B.F., 1973. The effect of organophosphorus compounds and oxime carbamates on the potato cyst nematode Heterodera rostochiensis Woll. Pesticide Science, 7(4), 459- 465. 
Hough, A., Thomason, I.J., 1975. Effects of aldicarb on the behavior of Heterodera schachtii and Meloidogyne javanica. Journal of Nematology, 7(3), 221-229.

Hough, A., Thomason, I.J., Farmer, W.J., 1975. Behavior of aldicarb in soil relative to control of Heterodera schachtii. Journal of Nematology, 7(3), 214-221.

Houghton, P.J., Ren, Y., Howes, M.J., 2006. Acetylcholinesterase inhibitors from plants and fungi. Natural Products Reports, 23(2), 181-199.

Huang, S.P., Resende, I.C., Souza, P.E., Campos, V.P., 1983. Effect of aldicarb, ethoprop and carbofuran on control of coffee root-knot nematodes Meloidogyne exigua. Journal of Nematology, 15(4), 510-514.

Huang, S.P., Van Gundy, S.D., 1976. Effects of aldicarb and its sulfoxide and sulfone on the biology of Tylenchus semipenetrans. Journal of Nematology, 10(2), 100-106.

Hussey, R.S., Barker, K.R., 1973. A comparison of methods for colecting inocula of Meloidogyne spp. including a new technique. Plant Disease Repórter, 57(12), 1025-1028.

Jardim, I.N., Oliveira, D.F., Silva, G.H., Campos, V.P., Souza, P.E., 2018. Cinnamaldehyde from the essential oil of Cinnamomum cassia controls Meloidogyne incognita in soybean plants. Journal of Pesticide Science, 91(1), 479-487.

Kang, J.S., Kim, E., Lee, S.H., Park, I.K., 2013. Inhibition of acetylcholinesterases of the pinewood nematode, Bursaphelenchus xylophilus, by phytochemicals from plant ssential oils. Pesticide Biochemistry and Physiology, 105(1), 50-56.

Miller, P.M., 1970. Failure of several non-volatile and contact nematicides to kill eggs in cysts of Heterodera tabacum. Plant Disease Reporter, 54(8), 781-783.

Nelmes, A.J., 1970. Behavioral responses of Heterodera rostochiesis larvae to aldicarbe and its sulfoxide and sulfone. Journal of Nematology, 2(3), 223-227.

Nelmes, A.J., 1971. The permeability of nematodes to aldicarbea nematicidal oxime carbamato. Mededelingen Faculteit Landbomwwetenschappen, 36(1), 904-914.

Opperman, C.H., Chang, S., 1991. Effects of aldicarb and fenamiphos on acetylocholinesterase and motility of Caenorhabditis elegans. Journal of Nematology, 23(1), 20-27.

Piffer, R., Rigitano, R.L.O., 1991. Lixiviação e degradação do inseticida aldicarbe em dois diferentes solos. Ciência e Prática, 15(3), 355-363.

R Development Core Team, 2009. R: A language and environment for statistical computing. http://www.Rproject.org (acessado 25 de maio de 2009).
Rocha, F.S., Campos, V.P., 2003. Efeito de baixa dose de aldicarbe nos processos de eclosão a penetração de juvenis do segundo estádio de Meloidogyne incognita. Nematologia Brasileira, 27(2), 185-192.

Rocha, F.S., Campos, V.P., Fernandes, M.F.G., Muniz, M.F.S., 2016. Migration and reproduction of Meloidogyne incognita in two soil textures. Nematropica, 46(2), 162-171.

Rocha, F.S., Catão, H.C.R.M., Muniz, M.F.S., Campos, V.P., Civil, N., 2015. Correlation among methods to estimate lipid reserves of second-stage juveniles and its relatioship with infectivity and reproduction of Meloidogyne incognita. Nematology, 17(3), 345-352.

Schuske, K., Begy, A.A., Jorgensen, E.M., 2004. The GABA nervous system in Caenorhadditis elegans. Trends in Sheuroscience, 27(4), 407-414.

Sikora, R.A., Hartwig, J., 1991. Mode-of-action of the carbamate nematicides cloethocarb, aldicarb and carbofuran on Heterodera schachtii: 2. systemic ativity. Revue de Nématologie, 14(4), 531-536.

Silva, E.H., Campos, V.P., Rocha, F.S., Zeviani, W.M., Terra, W.C., Rigitano, R.L.O., 2019. Efeito do aldicarbe no ciclo de vida de Meloidogyne incognita. Revista de Agricultura Neotropical, 6(3), 82-91.

Steele, A.E., Hodges, L.R., 1975. In vitro and in vivo effects of aldicarb on survival and development of Heterodera schachtii. Journal of Nematology, 7(3), 305-312.

Stewart, G.R., Perry, R.N., Wright, D.J., 1994. Immunocytochemical studis in the occurrence of gammaaminobutyric acid (GABA) in the nervous system of the nematodes Panagrellus redivivus, Meloidogyne incognita and Globodera rostochiensis. Fundamental and Applied Nematology, 17(5), 433-439.

Stewart, G.R., Perry, R.N., Wright, D.J., 2001. Occurrence of dopamine in Panagrellus redivivus and Meloidogyne incognita. Nematology, 3(6), 843-848.

Van Gundy, S.D.V., Bird, A.F., Wallace, H.R., 1967. Aging and starvation in juvenile of Meloidogyne javanica and Tylenchulus semipenetras. Phytopathology, 57(6), 559-571.

Van Gundy, S.D.V., Mckerry, M.V., 1977. Action of nematicides, in: Horsfall, J.G., Cowling, E.B., (Ed.), Plant disease: an advanced treatise. Academic, New York, p. 263-280.

Wang, K., Luo, C., Liu, H., Xu, J., Sun, W., Zhou, L., 2012. Nematicidal activity of the alkaloids from Macleaya cordata against certain nematodes. African Journal of Agricultural Research, 7(44), 5925-5929.

Wright, D.J., Perry, R.N., 2006. Reproduction, physiology and biochemistry, in: Perry, R.N., Moens, M., (Ed.), Plant nematology. Walhingford, CAB International, p. 187-209. 